Article

\title{
Enhancement of Small Towns in Inland Areas. A Novel Indicators Dataset to Evaluate Sustainable Plans
}

\author{
Antonio Nesticò * (D), Pierfrancesco Fiore and Emanuela D’Andria \\ Department of Civil Engineering, University of Salerno, Via Giovanni Paolo II, 132-84084 Fisciano, Italy; \\ pfiore@unisa.it, (P.F.); emdandria@unisa.it (E.D.) \\ * Correspondence: anestico@unisa.it; Tel.: +39-089-96-4318
}

Received: 25 June 2020; Accepted: 4 August 2020; Published: 7 August 2020

\begin{abstract}
In response to the abandonment and depopulation of small towns in inland areas, it is necessary to provide analysis and technical-economic evaluation tools with the aim of selecting effective recovery and valorization strategies. In the light of what criteria and indicators should this selection be carried out? The principles of sustainability guide us to a new definition of social, economic, environmental, and historical-architectural criteria. The intention is to outline a new way of classifying the judgment criteria, exclusively referring to the peculiarities of small towns. In turn, the criteria are specifically defined in sixteen sub-criteria, again able to represent the salient features of small municipalities: Local traditions, genius loci, urbanization levels, but also prevailing economy, environmental (flora and fauna, water, soil, air, etc.), and historical-architectural components (relations between the small town and the immediate context, formal relationship between building and urban core, etc.). This is followed by the drafting of a novel dataset of evaluation indicators, capable of expressing the project actions' capacity to pursue the objectives expressed by the criteria. These are datasets that give back 24 indicators for the social sub-criteria, 42 for the economic sub-criteria, 34 for the environmental ones, and 38 for the historical-architectural ones. The goal-criteria-subcriteria-indicators structure outlined in this paper opens up research perspectives on the characterization of a hierarchical model of multi-criteria analysis.
\end{abstract}

Keywords: sustainable development; small towns valorization; architectural recovery; analytic hierarchy process (AHP); multi-criteria indicators; economic evaluation

\section{Introduction}

The depopulation of small towns is a current problem that affects many European and non-European Countries. The exodus to the cities intensified at the beginning of the 20th century, when industrial development and the systematic drainage of the plains encouraged strong migration of workers from the hilly areas to the valley floors. With the industrial progress of the post-war period, this phenomenon is increasing together with the rapid expansion of urban areas. The results of growth are the fragmentation of the countryside, the uncontrolled consumption of land, and the abandonment of small towns: The places that previously ensured subsistence are no longer considered suitable for 'contemporary living'. Thus, new housing and work needs lead residents to prefer the metropolis rather than the rural areas. In addition, the little or no employment opportunities, the considerable distance from major service centres, and the inadequacy of infrastructure contribute to the shrinkage of small settlements. The direct consequences are their cultural, social, and economic isolation, together with the degradation of the built heritage and the impoverishment of the productive fabric [1].

However, the interest in these realities is attested by the gradual awareness of their potential. 
Small municipalities are models of 'slow living', witnesses of national and identity consciences: «Emotional territories, they are a kaleidoscope of historical and collective memories, full of cultural and environmental heritage, of historical and folk traditions, of flavours, colours and perfumes» [2] (p. 47). At the time of metropolitan and environmental crisis, small towns are also seen as a real opportunity for the sustainable development of nations. Moreover, «the city [...] needs to create a balanced relationship with the surrounding territory because it shares with it the environmental resources on which the most important challenges for the future of metropolitan areas depend. It is for this reason that the debate around small towns is also involving large urban centres» [3] (p. 12).

Therefore, valorizing and protecting small territorial realities is a moral and essential duty. Nevertheless, any project cannot consider the simple conservation of architectural artefacts, but must also involve the social, anthropological, environmental, cultural, and economic components: «It seems clear that the recovery of villages should not be understood only and necessarily as an operation of maintenance and restoration of the historical heritage for cultural and tourist purposes, but means returning to inhabit the territory in order to re-establish a broken relationship with nature, different case by case. From this point of view, the buildings and people's memory is essential in not losing a knowledge and culture heritage inextricably linked to the natural and artificial places built over the centuries» [3] (p. 13).

With these premises, the work faces the valorization of small towns in inland areas according to the sustainable development axioms. The several tangible and intangible factors that characterize small municipalities, as well as the need for organic programmatic actions, require the definition of operational tools useful to select effective intervention strategies. This must be done in the light of multiple evaluation criteria-social, economic, environmental, historical-architectural—which can be organised in a multi-criteria economic analysis model.

Multiple-criteria decision analysis (MCDA) allows us to express convenience judgements on investment options based on several criteria. The MCDA supports the decision-maker in solving complex problems, which raise heterogeneous and conflicting issues. This determines compromise solutions capable of balancing the pursuit of pre-established objectives with a view to maximising the collective well-being $[4,5]$.

The efficacy of multi-criteria techniques is demonstrated in literature. In fact, many sectors make use of these techniques [6-15]. The list is long: Tourism menagement, production management, safety and risk management, manufacturing systems, information technology management, operation research and soft computing, strategic menagement, energy-environmental and sustainability, supply chain management, material, quality management, GIS, urban and territorial management, construction and project management, and knowledge management [16].

Whatever the field of reference is, and whatever the specific topic investigated is, it is always essential to have panels of criteria and corresponding indicators in order to correctly implement the pre-established model of analysis. In the present work, the characterization of a new scheme of criteria and indexes is proposed, outlining an innovative interpretative framework of the project actions' capacity to effectively valorize small towns.

\section{Aim of the Paper}

The aim of the research is to define criteria and corresponding indicators for the economic evaluation of projects specifically aimed at valorizing small towns in inland areas. This is done by reference to the sustainable development principles.

The study starts from the recognition of the social, economic, environmental, and historical-architectural components that are crucial in the process of selecting projects for the small towns' recovery and valorization. These elements lead to establishing the analysis criteria, which are then divided into sub-criteria according to the Analytic Hierarchy Process structure (AHP). 
The criteria schematization in accordance to the social, economic, environmental, and historical-architectural factors that characterize villages, the set of sub-criteria, as well as the determination of corresponding evaluation indicators, is the novelty of the paper, which intends to provide operators an information dataset useful to concretely use multi-criteria models for the selection of the most successful project options for small municipalities. This makes it possible to fill a literature gap, i.e., the lack of criteria, sub-criteria, and indicators precisely built for the technical-economic evaluation of investments in small towns.

From the beginning (Section 3), the literature review on the 'small town' definition is presented.

In Section 4, the importance of concrete actions for the recovery and enhancement of marginal territorial realities is attested to, from which it is clear the need to define an AHP model that includes social, economic, environmental, and historical-architectural parameters (Section 5). Following that, in Section 6, the sub-criteria and indicators for each of the above-mentioned four criteria are set out in a tabular form.

Finally, Section 7 illustrates the results achieved through a brief discussion. The conclusions (Section 8) summarize what has been exposed, highlighting its originality and the research perspectives.

\section{Literary Excursus on the 'Small Town' Definition}

Although it is difficult and complex to delineate concisely the definition of 'small town', it is equally useful to trace a semantic path on its meaning. To this end, it is appropriate to start from the broader concept of historic centre. With regard to Italy, even if the Gubbio Charter (1960) does not give a precise expression to the term, it is instead clear that there is an urgent need to safeguard «the whole historical city, the whole urban structure, as it has been slowly coming together over the centuries». It is only four years later that, in Declaration XL, the Commission of Inquiry for the Protection and Valorization of the Historical, Artistic and Landscape Heritage offers a first interpretation, enucleating historical centres as «those urban settlement structures that constitute cultural unity or the original and authentic part of settlements, and testify the features of a living urban culture». Moreover, of great importance is the consideration made by Di Gioia in 1975: «The notion of historical centre today tends to expand further, in order to cover all settlement contexts with historical relevance, whatever period they belong to [ ... ]. Historical centre is not only the ancient centre of a city [ ... ]. The expression 'historical centre' is taken to mean all those urban planning values, of architectural environment and art, which are intended to be protected today: including therefore every value that, in their history, critical and recent, the city, the small town, or even the most isolated and modest settlement, have been able to express» [17] (p. 25).

In this context, the first, although vague, reference to the small town concept can be traced back to 1964, the year of Declaration XL. In fact, with the Venice Charter, and in particular with art. 1, the 'monument' is no longer understood as a single valuable building, but as an «urban or landscape environment» that testifies a particular culture or an important historical event. In this wider meaning are also included the historical centres and the small towns, considered typical realities of the territory for their «spontaneous and vernacular expressions».

Seven years later (1971), Alberto Predieri at the VI Conference of the National Association of Historic-Artistic Centres distinguishes:

- The centres of big metropolitan areas;

- the small towns as urban nuclei included in fast or stationary development cities, originally key nodes of the territory as important places for economic and political-cultural activities; and

- abandoned small towns.

Moreover, in making the definition of small town, Predieri underlines its historical-artistic and environmental value together with the tourist-cultural one [18]. 
Interesting is the Roberto Di Stefano's thought that relates «the small urbanized towns» to a low number of inhabitants [19] (p. 51). Giuseppe Rocchi also highlights the relationship between small towns and population, talking about «urban agglomerations characterized by a few thousand inhabitants», usually located in marginal areas, rural or mountainous, subject to a significant demographic decrease [20] (p. 306).

Thus, a quantitative identification approach begins to be outlined. In this regard, Edoardo Detti's observation is significant: «The distinction that can be made is only of situation, environment and quantity; I would not say of value even if the city differs for a more durable and formally evolved building, and the small towns for a more rustic building» [18] (p. 20). Enrico Guidoni also refers to the functionality of a numerical definition, necessary «to delimit in first approximation the field of research» [21] (p. 5).

Moreover, it is interesting to underline that even in the European panorama, and more precisely during the Symposium on the conservation of smaller historic towns in 1975, M.A., Chastel assigned to the petites villes a range of inhabitants between 2000 and 20,000.

The expedience of adopting a maximum population threshold is also a prerogative of many Italian laws. The references are to No 11/1997 of Marche, No 37/1999 of Veneto, and the recent No 158/2017. The latter, extending to the entire national territory, allocates European funds to municipalities with a population of less than 5000 inhabitants. The aims are the recovery and valorization of these realities through the promotion of social, economic, cultural, and environmental development.

Hence, the urgency to have a dimensional-quantitative limit in view of possible application interventions. However, in order to have a more precise idea of the small town, it is equally essential to deepen the relationship between small municipalities and landscape. In this regard, it is good to remember that the word 'landscape' was coined in painting field during the late Middle Ages to describe «images that portrayed distant countries, trees, mountains, hills, scenes of countryside life [ ... ] descriptions of open spaces, where fields, tree-lined rows and architecture are in harmony with the natural setting». Furthermore, the most frequent expression to qualify the artistic genre to which it referred is «painting of villages' which used a word derived from the Latin pagus [...] with a reference to the border sign planted in the ground, and it indicated an administrative district, a rural territory, or, more broadly, a vast inhabited region» [22] (pp. 15-22).

The link between the built and the surrounding natural space is further highlighted in the German word Landshaft, adopted in the 9th century to indicate a limited territorial area, a district, or a village [22].

In addition to these considerations, there is the European Landscape Convention (2000) in which 'landscape' value is given to the built heritage harmoniously inserted in the environment. Here the landscape is understood as «a specific part of the territory, as perceived by the populations, whose character derives from the action of natural and/or human factors and their interrelationships». After all, the genius loci of a place springs from the balance between the aesthetics of the built-nature relationship and social, cultural, economic, and historical issues.

It is therefore plausible to recognize the small towns as a «'landscape within the landscape", as the action of man who, spontaneously, has modified the territory using local materials and resources, adapting to soil trends, climate and morphological structures. Places where intangible goods, localism, specificities and shared values are preserved» [23] (p. 1399).

\section{Small Towns and Valorization Actions}

As places of 'contraction', small towns are victims of depopulation and abandonment phenomena. The marginalization they suffer from, on the one hand has caused their cultural, social, and economic isolation, and on the other hand has allowed them to preserve intact a vast material and immaterial heritage «in an autonomy that, although not devoid of contemporaneity, represents an object of great interest not only in terms of memory conservation but also in terms of potential for composing qualitative social and settlement models» [2] (p. 15). 
The latent interest in small realities can already be traced back to the 19th century, when William Morris praised the high quality of the traditional built heritage [24]. The following century is characterized by many cultural events focused on the small settlements topic. Among these, Architecture without architects (1964), an exhibition organized at the MoMa by Bernard Rudofsky, which highlighted the indispensability of vernacular architecture, mostly unknown.

In 1979, Norman F. Carver Jr. lauded the small towns' human dimension, stressing the relevance of these places and the imminent risk of their disappearance. In fact, in the preface of his book Italian Hilltowns he writes: «Italians have built some of the most human scale cities in the world. The archetypes of these cities are the villages and the small towns where, free from conceptual and stylistic influences, the admirable harmony between Italian life and landscape has developed. The aim of this book is to document these villages and small towns, partly because their uniqueness is in danger of disappearing, and partly because the solutions they have given to universal problems deserve to be emulated from many points of view» [25] (p. 6).

Actually, however, a real interest in small settlements has only occurred in the last decade. The metropolis crisis, combined with the environmental one, makes it necessary to consider the marginal realities as a possible solution to mend the city-countryside relationship.

Indeed, rehousing small towns encourages healthy lifestyles and the setting up of community and identity links; it limits soil consumption and helps to reduce urban decongestion. In addition, «popular shapes are instructive, because they are a direct response to urgent common demands, to individual or collective needs and to the climatic characteristics of places. Their freedom from artificial constraints of taste or style gives us the possibility to understand more immediately how fundamental forces shape the built world» [25] (p. 7). It is, therefore, substantial to proceed with effective valorization interventions that aim at safeguarding the large small heritage: «It is a matter [...] of giving life to complex evaluations that allow to highlight problems and resources in order to elaborate strategies, in an integrated planning perspective» [18] (p. 77). So, actions directed not only to the building reuse, but also to the environmental and landscape protection, together with the infrastructural rehabilitation and social cohesion.

More specifically, the valorization of these realities includes: The recovery of material and immaterial potential; the re-proposal of productive vocations; the insertion of local values in a knowledge and promotion positive circuit. The revitalization of small towns is, therefore, possible in view of a sustainable development of the territories, since it is evident the need to consider social, economic, environmental, and cultural aspects. So, every project must inevitably be based on sustainability principles.

\section{Materials and Methods. A New Panel of Evaluation Criteria and Sub-Criteria}

In the light of the issues referred to in the previous paragraph, it is clear that there is a need to set up operational tools aimed at selecting suitable strategies for the valorization of small towns. The complexity of the actions to be performed and the multitude of factors to be considered in small towns orient towards the use of multi-criteria analysis models [26,27]. Among these, the Analytic Hierarchy Process $[28,29]$ is chosen, as it allows us to disaggregate the decision-making problem through a multi-level structure, which identifies in sequence:

- General goal (Level I);

- $\quad$ criteria by which to reach the goal (Level II);

- $\quad$ sub-criteria (Level III); and

- $\quad$ possible alternatives (Level IV).

The AHP requires the comparison in pairs among the elements of a same hierarchical level with each of the elements at the higher level. In this way the criteria are compared with the goal, the sub-criteria with the superordinate criterion, and the alternatives with the sub-criteria. The comparisons can be made using Saaty's fundamental scale, which makes verbal judgments in a range from 'equal' to 'extreme'. 
As is well known, comparisons in pairs $a_{i j}$ return square, symmetrical, and reciprocal matrixes such as:

$$
\mathrm{A}=\left|\begin{array}{cccc}
a_{11} & a_{12} & \ldots & a_{1 n} \\
a_{21} & a_{22} & \ldots & a_{2 n} \\
\vdots & \vdots & \vdots & \vdots \\
a_{n 1} & a_{n 2} & \ldots & a_{n n}
\end{array}\right|
$$

Once the evaluation matrixes are established, it is possible to calculate the eigenvector and consequently the components of the priorities vector. Thus, the priorities of the elements are expressed and the alternative that best pursues the overall goal is selected. The main eigenvector determines the matrixes' reliability [30].

With regard to the aims of the research, the definition of the criteria is carried out taking into account the different components of sustainable development. Therefore, the proposed criteria for the evaluation of small towns' valorization projects are: Social, economic, environmental, and cultural. The cultural component specifically evaluates the historical-architectural aspects of small towns.

Having decided the criteria, they are then characterised in sub-criteria. To this purpose, a study is conducted on the strengths and weaknesses of the generic small town, with the aim of identifying its constant characteristics. The 'invariants' so detected are:

- Presence of local traditions and identities;

- lack of services;

- typical production activities;

- distance from major cities;

- lack of adequate infrastructure;

- environmental quality;

- insertion in a natural context;

- limited and compact extension of the built fabric;

- 'human scale' dimension of the built;

- quality of the built heritage; and

- $\quad$ site-specific typological-constructive characters.

These recurrent characteristics are organized according to social, economic, environmental, and historical-architectural criteria and 'translated' into 16 sub-criteria. Table 1 shows the division of the 'invariants' into the 4 criteria and their declination into sub-criteria. 
Table 1. Correspondence between invariants and sub-criteria.

\begin{tabular}{|c|c|c|}
\hline Criterion & Invariant & Sub-Criterion \\
\hline \multirow{2}{*}{ Social } & Presence of local traditions and identities & Local traditions and identities \\
\hline & Lack of services & $\begin{array}{l}\text { Secondary urbanization works } \\
\text { Social assistance services }\end{array}$ \\
\hline \multirow{3}{*}{ Economic } & Typical production activities & Productive vocations \\
\hline & Distance from major cities & Primary urbanization works \\
\hline & Lack of adequate infrastructure & Primary urbanization works \\
\hline \multirow{3}{*}{ Environmental } & \multirow{3}{*}{ Environmental quality } & Flora and fauna \\
\hline & & $\begin{array}{l}\text { Environmental quality of water, air } \\
\text { and soil }\end{array}$ \\
\hline & & Green areas \\
\hline \multirow{6}{*}{ Historical-architectural } & \multirow{2}{*}{ Insertion in a natural context } & Integration with the environment \\
\hline & & Visual image \\
\hline & Limited and compact extension of the built fabric & $\begin{array}{l}\text { Dialogue between the urban fabric } \\
\text { and its context }\end{array}$ \\
\hline & 'Human scale' dimension of the built & $\begin{array}{l}\text { Empty/Full relationship and green } \\
\text { space system }\end{array}$ \\
\hline & Quality of the built heritage & $\begin{array}{l}\text { Formal relationship between the } \\
\text { building and the characteristics of the } \\
\text { urban core }\end{array}$ \\
\hline & Site-specific typological-constructive characters & $\begin{array}{l}\text { Typological-distributive and } \\
\text { typological-formal characteristics of } \\
\text { the building }\end{array}$ \\
\hline
\end{tabular}

In addition, the sub-criterion 'Bioclimatic quality' is chosen to be included in the environmental criterion with reference to the building system. Indeed, this sub-criterion is considered extremely significant within a possible valorisation project.

Thus, after obtaining the sub-criteria, Table 2 shows the hierarchical organization of all the elements.

Table 2. Hierarchical organization of the elements.

\begin{tabular}{|c|c|c|}
\hline \multirow[b]{3}{*}{$\begin{array}{l}\text { Valorization of } \\
\text { small towns }\end{array}$} & Social criterion & $\begin{array}{c}\text { Local traditions and identities } \\
\begin{array}{l}\text { Secondary urbanization works (kindergartens, schools, health facilities, } \\
\text { neighborhood markets, municipal delegations, churches and religious } \\
\text { buildings, sports facilities) }\end{array} \\
\text { Social assistance services (services for the elderly, for people with disabilities, } \\
\text { for immigrants) }\end{array}$ \\
\hline & Economic criterion & $\begin{array}{l}\text { Productive vocations (agriculture, crafts, industry, trade, tourism) } \\
\text { Primary urbanization works (roads serving the settlements, conduits suitable } \\
\text { for collecting and draining sewage, car parks, electricity network, telephone } \\
\text { network, gas network, public lighting, water network) }\end{array}$ \\
\hline & Environmental criterion & $\begin{array}{c}\text { Territory } \\
\text { Flora and fauna } \\
\text { Environmental quality (water, air, soil) } \\
\text { Urban core } \\
\text { Green areas } \\
\text { Building } \\
\text { Bioclimatic quality }\end{array}$ \\
\hline
\end{tabular}


For the environmental sub-criterion and the historical-architectural sub-criterion, it is proposed a detailed analysis referring to three different layers:

- Territory;

- urban core;

- building.

Social sub-criteria combine local traditions and identities with essential services. Among these, very important are the secondary urbanization works, which include schools of all levels, health facilities, churches, markets, etc.

Fundamental to the small towns' rebirth are also the productive vocations, i.e., the activities linked to agriculture, handicrafts, and industry. These, together with primary urbanization works (electricity, water, telephone and gas networks, but also roads and public lighting), promote the growth of the local economy

The environmental sub-criteria collect on a territorial scale the native fauna and plant elements, as well as other natural components such as water, air, and soil.

At the urban core level, the consistency and composition of green spaces is investigated.

Importance is also given to the bioclimatic characteristics of existing buildings.

The three layers' territory, urban core and building, already used for the organization of the environmental sub-criteria, are reproposed for the historical-architectural sub-criteria. With regard to the territorial dimension, attention is paid to landscape issues, linked to the formal relationship between the small town and its context. At the scale of the village, it is important to consider the visual image that it gives back, rendered through the correlations between buildings and empty spaces (squares, streets, alleys, stairways), and between the urban fabric and surrounding areas. Finally, the architectural artefact is studied not only in its formal relationship with the entire small town, but also in the typological characters that distinguish it.

\section{Novel Indicators Datasets for the Multi-Criteria Analysis of Small Towns Enhancement Plans}

At this point, evaluation indicators should be defined for each of the sub-criteria proposed in the previous paragraph. To this end, the reference literature is analysed in detail. More specifically, the small towns valorization topic requires the consideration of issues concerning: Urban sustainability, sustainable urban mobility, valorization of the historical-cultural heritage, territorial cohesion, rural development, and landscape. Figure 1 outlines the macro areas of research.

As a result of the investigation carried out on several datasets of indicators related to the macro areas of Figure 1, there is the selection of 15 international studies shown in Table 3. The parameters used for their choice are: Suitability to the main research goal, pertinence to the small towns' reality, setting clarity, easily available data, possibility of application to different city sizes. Thus, from the 15 studies, as many as 470 evaluation indicators are collated.

From the set of 470 indicators, those that best describe each of the 16 sub-criteria already set out in Table 2 are chosen. As Table 4 explains, this operation is conducted through six principles: 1 . Focus; 2. Relevance; 3. Accessibility; 4. Clarity; 5 . Cost; 6 . Frequency $[31,32]$. The preference of one indicator over another is therefore made through questions: Does the indicator in exam measure more accurately than another what is desired to be measured? Is the indicator more consistent to the research object than another? Is the indicator clearer in its definition than another? In doing so, all 470 indicators are compared with each other and evaluated on the basis of objective parameters.

At this point, it is possible to draw up four novel datasets of indicators to which operators can refer for the multi-criteria evaluation of plans and projects aimed at the sustainable development of small towns in inland areas. These are the four datasets in Tables 5-8, which respectively concern the social, economic, environmental, and historical-architectural criteria. 
For each indicator, the unit of measurement is specified, useful for the concrete application of the same indices in case studies. In this way, local administrations or designers can choose for each dataset one or more indicators suitable to evaluate the related sub-criteria. The choice is also made on the basis of the data that each expert has available for a project. So, the operator who wants to select an effective valorization strategy can choose the most relevant indexes for the specific case he is evaluating.

It should be noted that Tables 5-8 contain not only indicators chosen from those 470 that the literature proposes, but also completely new indices, specifically defined for the analysis of plans and projects regarding small towns.

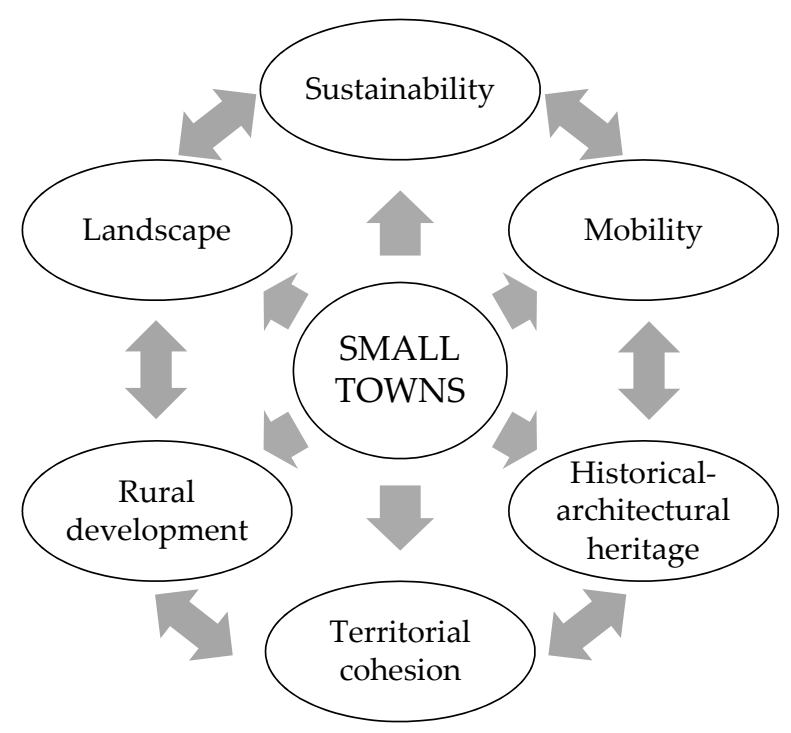

Figure 1. Macro thematic areas related to the valorization of small towns.

Table 3. Main bibliographical references and number of indicators.

\begin{tabular}{|c|c|}
\hline Reference Study & N. Indicators \\
\hline Mega V., Pedersen J. (1998), Urban Sustainability Indicators [33] & 16 \\
\hline European Commission (2008), European Green Capital Award & 12 \\
\hline Mameli F., Marletto G. (2009). A selection of indicators for monitoring sustainable urban mobility policies [34] & 14 \\
\hline Vallega A. (2009), Indicatori per il paesaggio [35] & 37 \\
\hline European Environment Agency (2010), EEA Urban Metabolism Framework $[36,37]$ & 15 \\
\hline $\begin{array}{c}\text { United Nations Economic Commission for Europe (UNECE) (2011), Transport for sustainable } \\
\text { development in the ECE region [38] }\end{array}$ & 17 \\
\hline Volpiano M. (2011), Indicators for the Assessment of Historic Landscape Features [39] & 12 \\
\hline Swiss Confederation (2012), Ufficio Federale dell'Ambiente UFAM - Paesaggio: Indicatori & 11 \\
\hline $\begin{array}{l}\text { EU Commission, Directorate-General for Agriculture and Rural Development (2013), Rural } \\
\text { Development in the European Union - Statistical and Economic Information, Report 2013 [40] }\end{array}$ & 59 \\
\hline $\begin{array}{c}\text { European Spatial Planning Observation Network (2013), KITCASP - Key Indicators for Territorial } \\
\text { Cohesion and Spatial Planning [41] }\end{array}$ & 20 \\
\hline $\begin{array}{c}\text { Phillips R. G., Stein J. M. (2013), An Indicator Framework for Linking Historic Preservation and Community } \\
\text { Economic Development [42] }\end{array}$ & 29 \\
\hline $\begin{array}{c}\text { Valtenbergs V., González A., Piziks R. (2013), Selecting indicators for sustainable development of small } \\
\text { towns: the case of Valmiera municipality [43] }\end{array}$ & 73 \\
\hline European Environment Agency (2014), Digest of EEA Indicators 2014 - Core Set of Indicators (CSI) [44] & 42 \\
\hline $\begin{array}{c}\text { UN-Habitat - United Nations Human Settlements Programme (2016), MEASUREMENT OF CITY } \\
\text { PROSPERITY - Methodology and Metadata [45] }\end{array}$ & 39 \\
\hline $\begin{array}{c}\text { Bosch P., Jongeneel S., Rovers V., Neumann H-M., Airaksinen M., Huovila A. (2017), CITYkeys list of } \\
\text { city indicators [46] }\end{array}$ & 74 \\
\hline TOTAL & 470 \\
\hline
\end{tabular}


Table 4. Criteria for the evaluation indices selection.

\begin{tabular}{|c|c|c|}
\hline \multirow{6}{*}{$\begin{array}{l}\text { Selective criteria of the } \\
\text { evaluation indices }\end{array}$} & Focus & $\begin{array}{l}\text { It is necessary to select indicators that measure only what } \\
\text { you want to measure }\end{array}$ \\
\hline & Relevance & $\begin{array}{l}\text { It is appropriate to choose the indicators most consistent } \\
\text { with the current study }\end{array}$ \\
\hline & Accessibility & It is meant to provide an easy way to find the required data \\
\hline & Clarity & $\begin{array}{l}\text { Clear and unambiguous interpretation indicators are taken } \\
\text { into account }\end{array}$ \\
\hline & Cost & $\begin{array}{c}\text { Preference is given to indicators whose data collection } \\
\text { requires little cost }\end{array}$ \\
\hline & Frequency & $\begin{array}{c}\text { That means choosing the indicators that repeatedly present } \\
\text { themselves }\end{array}$ \\
\hline
\end{tabular}

\subsection{Evaluation Indicators of the Small Towns' Social Components}

Table 5 sets out the novel characterization of the social criterion in the three sub-criteria:

1. Local traditions and identities;

2. secondary urbanization works; and

3. social assistance services.

Several evaluation indicators are proposed for each sub-criterion, accompanied by a brief description.

Great importance is given to the place's identity, as the result of a community's identification process with its environment. This natural 'context empathy', closely linked to emotional, cultural, and subjective issues, is essential in delineating the soul of a territory, its 'sense of being', and its immaterial richness $[47,48]$.

Attention is also paid to more concrete aspects, such as the presence of secondary urbanization works (education, health, commerce, leisure) and social assistance services.

Table 5. Social sub-criteria and indicators.

\begin{tabular}{|c|c|c|}
\hline \multicolumn{3}{|c|}{ Social Criterion } \\
\hline Sub-Criterion & Indicator & Description \\
\hline \multirow{7}{*}{$\begin{array}{l}\text { Local traditions and } \\
\text { identities }\end{array}$} & \multicolumn{2}{|r|}{ Indicated by literature } \\
\hline & $\begin{array}{l}\text { Sense of } \\
\text { place/identification with } \\
\text { place/attachement to place }\end{array}$ & $\begin{array}{l}\text { The way people perceive the resources and historical } \\
\text { environment of their community. There is an identity } \\
\text { linked to the place that evokes a special sense of place. } \\
\text { This indicator requires a direct survey among the } \\
\text { inhabitants of the historical sites }\end{array}$ \\
\hline & $\begin{array}{l}\text { The number of } \\
\text { cultural events }\end{array}$ & n. of cultural events \\
\hline & $\begin{array}{l}\text { The number of visitors in } \\
\text { cultural events }\end{array}$ & n. visitors in cultural events \\
\hline & \multirow[b]{3}{*}{ Taste's places } & $\begin{array}{l}\text { It is evaluated by the level at which the "taste's places" } \\
\text { enter into landscape valorization policies }\end{array}$ \\
\hline & & $I=\frac{G_{c}}{G_{t}} \times 100$ \\
\hline & & $\begin{array}{l}\mathrm{G}_{\mathrm{c}} \text { expresses the number of "taste's places" subject to } \\
\text { interventions and measures included in the territorial } \\
\text { plans, aimed at enhancing their value in relation } \\
\text { to the landscape. } \\
\mathrm{G}_{\mathrm{t}} \text { expresses the total number of "taste's places" existing in } \\
\text { the considered territory. }\end{array}$ \\
\hline
\end{tabular}


Table 5. Cont.

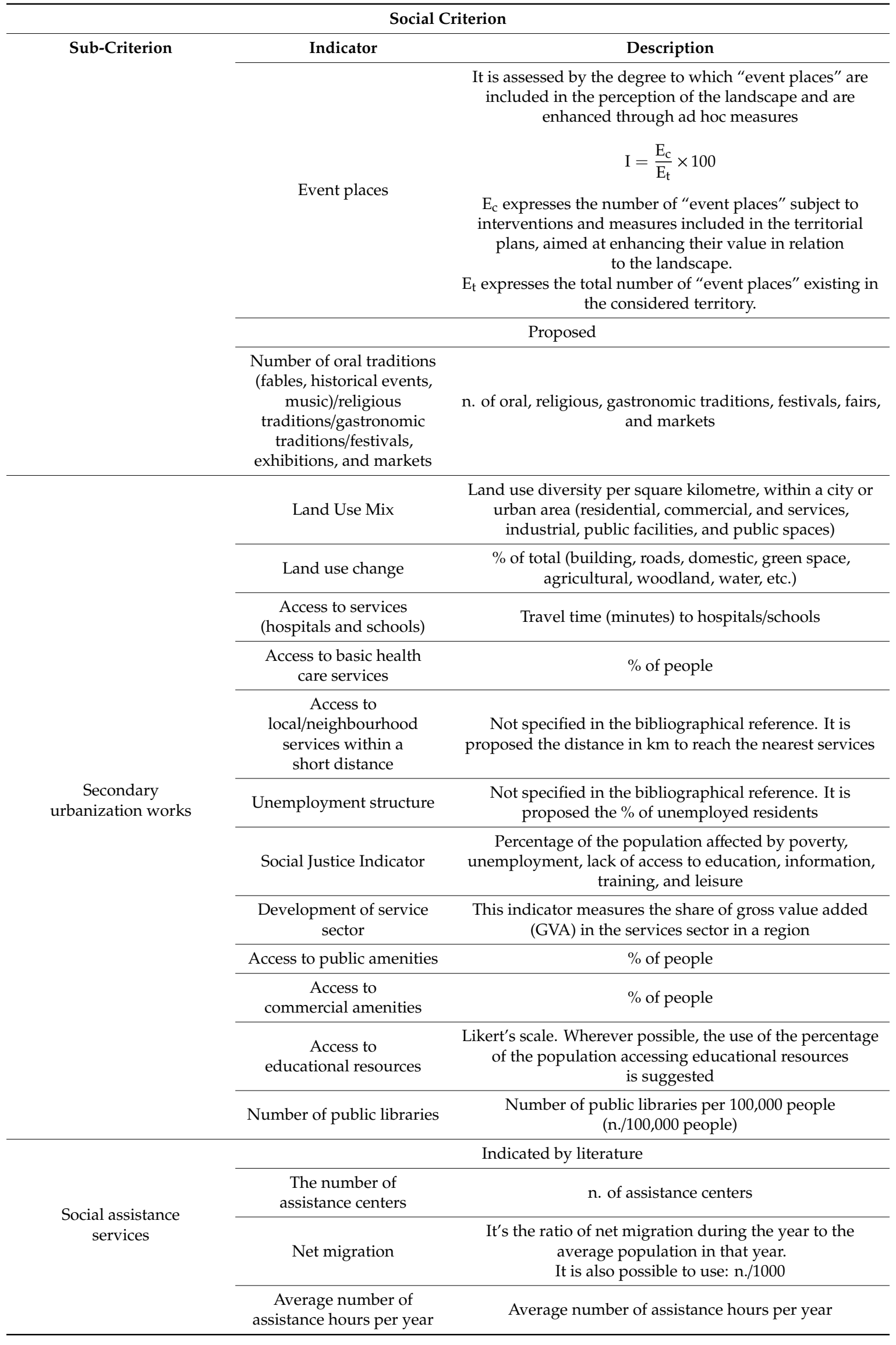


Table 5. Cont.

\begin{tabular}{|c|c|c|}
\hline \multicolumn{3}{|c|}{ Social Criterion } \\
\hline \multirow{3}{*}{ Sub-Criterion } & $\begin{array}{l}\text { Percentage difference } \\
\text { between the offered } \\
\text { services level and the } \\
\text { standard services level }\end{array}$ & $\begin{array}{c}\text { Percentage difference between the offered services level } \\
\text { and the standard services level }\end{array}$ \\
\hline & & Proposed \\
\hline & $\begin{array}{l}\text { Percentage of those who } \\
\text { benefit from social } \\
\text { assistance services on the } \\
\text { resident population }\end{array}$ & $\begin{array}{l}\% \text { population benefiting from social assistance } \\
\text { services/total resident population }\end{array}$ \\
\hline
\end{tabular}

\subsection{Economic Indicators}

For the economic criterion, Table 6 shows the division into two sub-criteria proposed in this research:

1. Productive vocations, and

2. primary urbanization works.

Both sub-criteria are considered essential for the development of small realities since, in addition to increasing their employment opportunities, they also promote tourism. The evaluation indicators focus on efficient land use, considering both agricultural and livestock areas. In addition, the industrial and hotel sectors are also taken into account.

Obviously, productive vocations cannot be increased without suitable primary urbanization works. Among these, the road system, public transport, electricity, gas, water, and internet networks are fundamental. The strengthening of this infrastructure means raising the quality of life and encouraging settlement in small towns.

Table 6. Economic sub-criteria and indicators.

\begin{tabular}{|c|c|c|}
\hline \multicolumn{3}{|c|}{ Economic Criterion } \\
\hline Sub-Criterion & Indicator & Description \\
\hline \multicolumn{3}{|r|}{ Indicated by literature } \\
\hline \multirow{6}{*}{ Productive vocations } & $\begin{array}{l}\text { Forest areas extensively } \\
\text { exploited }\end{array}$ & $\begin{array}{l}\text { Not specified in the bibliographical reference. It is } \\
\text { proposed the surface in } \mathrm{m}^{2} \text { of extensively exploited } \\
\text { forest areas }\end{array}$ \\
\hline & Agricultural areas & $\begin{array}{l}\text { Not specified in the bibliographical reference. It is } \\
\text { proposed the surface in } \mathrm{km}^{2} \text { of agricultural areas }\end{array}$ \\
\hline & \multirow{3}{*}{ Economic specialization } & $\begin{array}{l}\text { Shows the level (high or low) through which a city focuses } \\
\text { its economic activities on certain goods and services }\end{array}$ \\
\hline & & $H=\sum_{i=1}^{N} S_{i}^{2}$ \\
\hline & & $\begin{array}{c}S_{i}^{2} \text { is the employment share in the city's industry. } S_{i}^{2} \text { share } \\
\text { is expressed with a number and not a percentage. } \\
N \text { is the total number of industries. } \\
H \text { varies from } 1 / \mathrm{N} \text { to } 1 \text {. A value of } H \text { greater than } 0.25 \\
\text { indicates a high concentration }\end{array}$ \\
\hline & Structure of the economy & $\%$ GVA by branch (primary/secondary/tertiary sector) \\
\hline
\end{tabular}


Table 6. Cont.

\begin{tabular}{|c|c|c|}
\hline \multicolumn{3}{|c|}{ Economic Criterion } \\
\hline & Land use efficiency & $\begin{array}{l}\text { Not specified in the bibliographical reference. It is } \\
\text { proposed to make use of expert judgements, from which a } \\
\text { quantitative evaluation algorithm can be deduced }\end{array}$ \\
\hline & $\begin{array}{l}\text { Distribution of businesses } \\
\text { and employed by } \\
\text { industries }\end{array}$ & $\begin{array}{l}\text { Not specified in the bibliographical reference. It is } \\
\text { proposed the number of employees in the industrial sector }\end{array}$ \\
\hline & The number of tourists & $\begin{array}{l}\text { Not specified in the bibliographical reference. It is } \\
\text { proposed the number of tourists compared to the } \\
\text { resident population }\end{array}$ \\
\hline & Foreign Direct Investments & Capital/Earnings \\
\hline & $\begin{array}{l}\text { Dynamics of foundation } \\
\text { and dissolution of local } \\
\text { businesses }\end{array}$ & $\begin{array}{l}\text { Not specified in the bibliographical reference. An } \\
\text { economic indicator is proposed, depending on the level of } \\
\text { information available }\end{array}$ \\
\hline & The number of guest nights & Number of guest nights \\
\hline & $\begin{array}{l}\text { Economic enhancement of } \\
\text { historical-cultural heritage } \\
\text { networking }\end{array}$ & $\begin{array}{l}\text { It is proposed to evaluate this parameter according to the } \\
\text { specificities of the case study }\end{array}$ \\
\hline & Agricultural land use & $\begin{array}{l}\% \text { of Utilised agricultural area (UAA) in arable } \\
\text { land/permanent pasture/permanent crops }\end{array}$ \\
\hline & Local food production & $\%$ of tonnes \\
\hline & Green jobs & $\%$ of jobs \\
\hline & Land use change & $\begin{array}{l}\% \text { of total (building, roads, domestic, green space, } \\
\text { agricultural, woodland, water, etc.) }\end{array}$ \\
\hline & & Proposed \\
\hline & Prevailing cultivation & $\%$ of cultivations \\
\hline \multirow{6}{*}{$\begin{array}{l}\text { Primary urbanization } \\
\text { works }\end{array}$} & $\begin{array}{l}\text { Length of mass transport } \\
\text { network }\end{array}$ & $\mathrm{Km} / 1,000,000$ people \\
\hline & $\begin{array}{l}\text { Length of bike route } \\
\text { network }\end{array}$ & $\%$ in $\mathrm{km}$ \\
\hline & $\begin{array}{l}\text { Public transport network } \\
\text { length }\end{array}$ & $\begin{array}{l}\text { Not specified in the bibliographical reference. It is } \\
\text { proposed the route length in } \mathrm{km} \text { (tram, trolleybus, bus) }\end{array}$ \\
\hline & Street intersection density & $\begin{array}{l}\text { Number of street intersections per one square kilometer of } \\
\text { urban area }\left(\mathrm{n} . / \mathrm{km}^{2}\right)\end{array}$ \\
\hline & Street density & $\begin{array}{l}\text { Number of kilometers of urban streets per square } \\
\text { kilometer of land }\left(\mathrm{km} / \mathrm{km}^{2}\right)\end{array}$ \\
\hline & Infrastructure density & $\mathrm{km}$ of roads per 1,000 inhabitants \\
\hline
\end{tabular}


Table 6. Cont.

\begin{tabular}{|c|c|c|}
\hline \multicolumn{3}{|c|}{ Economic Criterion } \\
\hline & $\begin{array}{l}\text { The number of public } \\
\text { Wi-Fi places }\end{array}$ & Number of public spaces equipped with Wi-Fi \\
\hline & $\begin{array}{l}\text { Public and private services } \\
\text { accessibile via telephone } \\
\text { and computer }\end{array}$ & $\begin{array}{l}\text { Not specified in the bibliographical reference. The } \\
\text { indicator should be chosen according to the } \\
\text { data availability }\end{array}$ \\
\hline & $\begin{array}{l}\text { Transportation mode split } \\
\text { (percentage of each mode } \\
\text { of transportation, i.e., } \\
\text { private, public, bicycles, } \\
\text { pedestrians) }\end{array}$ & $\%$ of each transport mode (public, private, cycle, walking) \\
\hline & Internet infrastructure & Families with DSL coverage (\%) \\
\hline & $\begin{array}{c}\text { Internet take-up in rural } \\
\text { areas }\end{array}$ & $\begin{array}{l}\text { Families with a broadband connection contract (\% of } \\
\text { families with at least one member aged between } 16 \text { and } \\
74 \text { years) }\end{array}$ \\
\hline & Access to electricity & Percentage of families connected to the national network \\
\hline & Access to public transport & $\%$ of people \\
\hline & $\begin{array}{l}\text { Access to high speed } \\
\text { internet }\end{array}$ & $\%$ of people \\
\hline
\end{tabular}

\subsection{Environmental Indicators}

The environmental sub-criteria are organised into three distinct levels (Table 7) relating to:

1. Territory;

2. urban core; and

3. building.

Thus, it is possible to proceed from the analysis on a territorial scale to that of the settlement and of the building system.

The aspects addressed concern the vegetative cover, the climatic and environmental characteristics of the place, the presence of natural elements such as rivers, lakes, etc. In addition, there are the bioclimatic parameters of the single architectural building: Thermal insulation, indoor ventilation, room lighting.

In general, the environmental quality in small towns is high, and any project must take this pre-requisite into account, respect it, and enhance it. This means: Containing emissions of pollutants into soil, water and air; increasing wooded areas, preserving local biodiversity; and using renewable sources for sustainable land development. 
Table 7. Environmental sub-criteria and indicators.

\begin{tabular}{|c|c|c|}
\hline Sub-Criterion & Indicator & Description \\
\hline \multicolumn{3}{|c|}{ Territory } \\
\hline \multirow{20}{*}{ Flora and fauna } & Land cover & $\%$ area in agricultural/forest/natural/artificial classes \\
\hline & Protected forest & $\begin{array}{l}\text { Not specified in the bibliographical reference. It is } \\
\text { proposed an evaluation based on the extension in } \mathrm{m}^{2}\end{array}$ \\
\hline & $\begin{array}{l}\text { The number of protected } \\
\text { animal and plant species }\end{array}$ & n. of protected animal and plant species \\
\hline & $\begin{array}{l}\text { Percentage of preserved } \\
\text { area/reservoirs/waterways/ } \\
\text { in relation to total land area }\end{array}$ & $\begin{array}{l}\text { rks areas, reserves, rivers, protected parks in relation to the } \\
\text { total territorial area }\end{array}$ \\
\hline & $\begin{array}{l}\text { Species and habitats of } \\
\text { European interest }\end{array}$ & $\begin{array}{l}\text { Not specified in the bibliographical reference. It is } \\
\text { proposed the use of a numerical or percentage data }\end{array}$ \\
\hline & $\begin{array}{l}\text { Number and status of } \\
\text { protected European } \\
\text { habitats and species }\end{array}$ & $\begin{array}{l}\text { Number and Conservation Status (EU defined status of } \\
\text { Natura } 2000 \text { sites-SACs and SPAs and Annexed species) }\end{array}$ \\
\hline & Designated areas & $\begin{array}{c}\mathrm{km}^{2}, \% \text {, number of species and habitats listed by the } \\
\text { Habitats Directive }\end{array}$ \\
\hline & Land take & hectares or $\mathrm{km}^{2}$ \\
\hline & Urban land take & $\begin{array}{l}\% \text { of land that is converted from natural and semi-natural } \\
\text { areas (including wooded and agricultural areas) to } \\
\text { artificial land used for urban and economic purposes }\end{array}$ \\
\hline & $\begin{array}{l}\text { Proportion of protected } \\
\text { areas }\end{array}$ & $\begin{array}{c}\text { Not specified in the bibliographical reference. It is } \\
\text { proposed the \% of protected natural areas on the total } \\
\text { number of existing natural areas }\end{array}$ \\
\hline & $\begin{array}{l}\text { Biodiversity: Tree species } \\
\text { composition }\end{array}$ & $\begin{array}{c}\text { Area of forest classified by number of tree species } \\
\text { occurring and by forest type }(\%)\end{array}$ \\
\hline & $\begin{array}{l}\text { Biodiversity: Protected } \\
\text { forest }\end{array}$ & $\begin{array}{c}\text { _share of FOWL protected under MCPFE classes (\%) } \\
\text { _ change of FOWL area protected under MCPFE classes } \\
\text { (ha) }\end{array}$ \\
\hline & Forest ecosystem health & $\begin{array}{c}\% \text { of sampled trees in defoliation classes } 2-4 \text { (all } \\
\text { trees/conifers/broadleaves) }\end{array}$ \\
\hline & $\begin{array}{l}\text { Protected areas and } \\
\text { elements }\end{array}$ & $\begin{array}{l}\text { Surface extension. Level of environmental protection. } \\
\text { Number of protected elements. Other specific indicators }\end{array}$ \\
\hline & \multirow{3}{*}{$\begin{array}{l}\text { Ecologically protected } \\
\text { areas }\end{array}$} & $\begin{array}{c}\% \text { of surface area subject to ecological protection measures } \\
\text { in relation to the total surface area }\end{array}$ \\
\hline & & $\mathrm{I}=\frac{\mathrm{S}_{\mathrm{p}}}{\mathrm{S}_{\mathrm{t}}} \times 100$ \\
\hline & & $\begin{array}{l}\mathrm{S}_{\mathrm{p}} \text { is the area in hectares (ha) subject to protection } \\
\text { measures. } \\
\mathrm{S}_{\mathrm{t}} \text { is the total area, expressed in hectares (ha), of the } \\
\text { considered territory. }\end{array}$ \\
\hline & \multirow{3}{*}{ Protected species } & $\begin{array}{l}\% \text { of protected plant and/or animal species in relation to all } \\
\text { existing plant and/or animal species }\end{array}$ \\
\hline & & $I=\frac{S_{p}}{S_{t}} \times 100$ \\
\hline & & $\begin{array}{l}\mathrm{S}_{\mathrm{p}} \text { is the number of species, belonging to the wild } \\
\text { vegetation, subject to protective measures. } \\
\mathrm{S}_{\mathrm{t}} \text { is the number of species, belonging to spontaneous } \\
\text { vegetation, existing at the time the survey is carried out }\end{array}$ \\
\hline
\end{tabular}


Table 7. Cont.

\begin{tabular}{|c|c|c|}
\hline Sub-Criterion & Indicator & Description \\
\hline \multirow{13}{*}{$\begin{array}{l}\text { Environmental } \\
\text { quality }\end{array}$} & $\begin{array}{c}\text { Renewable energy } \\
\text { production (wind, hydro, } \\
\text { biomass, etc.) }\end{array}$ & Megawatts and $\%$ by renewable energy type \\
\hline & Greenhouse gas emissions & Tonnes $\mathrm{CO}_{2}$ eq. per individual \\
\hline & Water quality & Specific quality indicator \\
\hline & Water quality status & $\begin{array}{c}\text { Absolute values on the actual status or objective met/failed } \\
\text { (as per WFD for groundwater, rivers, lakes, } \\
\text { estauarine, coastal) }\end{array}$ \\
\hline & Air quality & Specific quality indicator \\
\hline & $\begin{array}{l}\text { Emissions of main air } \\
\text { pollutants }\end{array}$ & Specific indicator \\
\hline & $\begin{array}{l}\text { Exposure of ecosystems to } \\
\text { acidification, } \\
\text { eutrophication and ozone }\end{array}$ & Specific indicator \\
\hline & $\begin{array}{l}\text { Exceedance of air quality } \\
\text { limit values in urban areas }\end{array}$ & Specific indicator \\
\hline & $\begin{array}{l}\text { Atmospheric greenhouse } \\
\text { gas concentrations }\end{array}$ & Specific indicator \\
\hline & $\begin{array}{l}\text { Green growth and } \\
\text { eco-innovation }\end{array}$ & Specific indicator \\
\hline & $\begin{array}{l}\text { Global Climate Indicator } \\
\text { (GCI) }\end{array}$ & Emitted total $\mathrm{CO}_{2}, \mathrm{CH}_{4}, \mathrm{~N}_{2} \mathrm{O}$ and $\mathrm{CFCs}$ and halons \\
\hline & $\mathrm{CO}_{2}$ emissions & Specific indicator \\
\hline & $\begin{array}{l}\text { Emission of greenhouse } \\
\text { gases and local pollutants }\end{array}$ & Specific indicator \\
\hline \multicolumn{3}{|c|}{ Urban core } \\
\hline \multirow{2}{*}{ Green areas } & Green area per capita & Green surface per capita \\
\hline & Green space & Hectares/100,000 \\
\hline \multicolumn{3}{|c|}{ Building } \\
\hline \multirow{4}{*}{ Bioclimatic quality } & \multicolumn{2}{|r|}{ Proposed } \\
\hline & Shape and orientation & Type of shape. Building orientation \\
\hline & Ventilation quality & Presence/absence of internal ventilation. Ventilation level \\
\hline & Energy class & Level \\
\hline
\end{tabular}

\subsection{Historical-Architectural Indicators}

Like the environmental criterion, the historical-architectural one is also divided by levels: Territory; urban core; building.

The first layer (territory) is closely related to the landscape. It refers, in fact, to the fragility of environmental contexts, but also to their exceptionality and uniqueness. The integration of the small town with the environment is a complex concept, which is characterized by multiple indicators: Settlement dispersion; perceived value of the landscape skyline; injured landscape; etc.

The urban core scale is crucial because it is the link between the built heritage and its context.

This relationship must necessarily be preserved because, in addition to composing 'the soul of places', it is a determining factor for the small town's 'beauty'. To this end, it is opportune to conserve unaltered the harmonious image of the village, both in relation to its volumetry and its spatiality.

Referring then to the building system, issues related to the use of architectural artefacts, their protection, and conservation level are considered.

It is evident that the proposed characterization of the historical-architectural sub-criteria is mostly based on subjective judgements, dictated by the operator's sensibility. Translating 'emotional feelings' 
arising from the suggestion of small towns into quantitative data could be a forced operation, which would hardly respect the small settlement's nature.

Thus, in the light of the above, Table 8 shows the proposed historical-architectural sub-criteria and the corresponding indicators.

Table 8. Historical-architectural sub-criteria and indicators.

\begin{tabular}{|c|c|c|}
\hline \multicolumn{3}{|c|}{ Historical-Architectural Criterion } \\
\hline Sub-Criterion & Indicator & Description \\
\hline \multicolumn{3}{|c|}{ Territory } \\
\hline \multirow{4}{*}{$\begin{array}{l}\text { Integration with the } \\
\text { environment }\end{array}$} & \multicolumn{2}{|r|}{ Indicated by literature } \\
\hline & $\begin{array}{l}\text { Exceptionality of the } \\
\text { historical-cultural characteristics } \\
\text { of the landscape }\end{array}$ & Score scale \\
\hline & $\begin{array}{l}\text { Fragility of the historical-cultural } \\
\text { characteristics of the landscape }\end{array}$ & Score scale \\
\hline & Designation of rural areas & $\begin{array}{l}\text { "[... If more than } 50 \% \text { of the total population lives in rural grid } \\
\text { cells, the region is classified as predominantly rural. Regions } \\
\text { where between } 20 \% \text { and } 50 \% \text { of the population lives in rural grid } \\
\text { cells are considered intermediate, while those with less than } 20 \% \\
\text { in rural grid cells are predominantly urban» }\end{array}$ \\
\hline
\end{tabular}

\begin{tabular}{cc}
\hline Protected areas and elements & $\begin{array}{r}\text { Surface extension. Level of environmental protection. Number of } \\
\text { protected elements. Other specific indicators }\end{array}$ \\
\hline
\end{tabular}

Urban penetration units per $\mathrm{km}^{2}$ of landscape (DSE $/ \mathrm{km}^{2}$ )

Alternatively, it can be replaced with an urban sprawl index

Settlement dispersion

$$
\mathrm{IS}_{\mathrm{i}}=\frac{\left[\mathrm{urb}_{\mathrm{i}, \mathrm{t}+\mathrm{n}}-\left(\mathrm{urb}_{\mathrm{i}, \mathrm{t}} \times\left(\frac{\text { pop }_{\mathrm{i}, \mathrm{t}+\mathrm{n}}}{\text { pop }_{\mathrm{i}, \mathrm{t}}}\right)\right)\right]}{\mathrm{urb}_{\mathrm{i}, \mathrm{t}}} \times 100
$$

i refers to an urban area.

$t$ to the initial year of investigation and $t+n$ to the final year. urb refers to the built area (in terms of land consumed) expressed in $\mathrm{km}^{2}$ within administrative boundaries. pop is the total population of the municipality

Visual and aesthetic impact produced by human presence and activities on the skyline (linear/areal impact coefficient)

$$
\begin{aligned}
& I=\frac{L_{i}}{L_{b}} \\
& I=\frac{S_{i}}{S_{c}}
\end{aligned}
$$

Landscape value of skyline

$\mathrm{L}_{\mathrm{i}}$ expresses the overall length of the lines drawn by human works (roads, railways, and so on) engraved on the skyline, measured on the outline of the territory that appears from the photographic vision and/or cartographic representation.

$\mathrm{L}_{\mathrm{b}}$ expresses the baseline length delimited by that portion of the skyline.

$S_{i}$ expresses the total surface area of the area engravings produced by human communities on the outline delimited by the skyline. $\mathrm{S}_{\mathrm{c}}$ expresses the surface area limited by the skyline

Representative indices of human impact on the landscape

$$
\mathrm{I}=\frac{\mathrm{A}_{\mathrm{f}}}{\mathrm{A}_{\mathrm{t}}} \times 100
$$

Injured landscape

$A_{f}$ represents the sum of the surface area, measured in hectares (ha), of areas occupied by landfills and quarries, as well as areas degraded due to hydrogeological instability.

$\mathrm{A}_{t}$ represents the total suburban area of the considered territory 
Table 8. Cont.

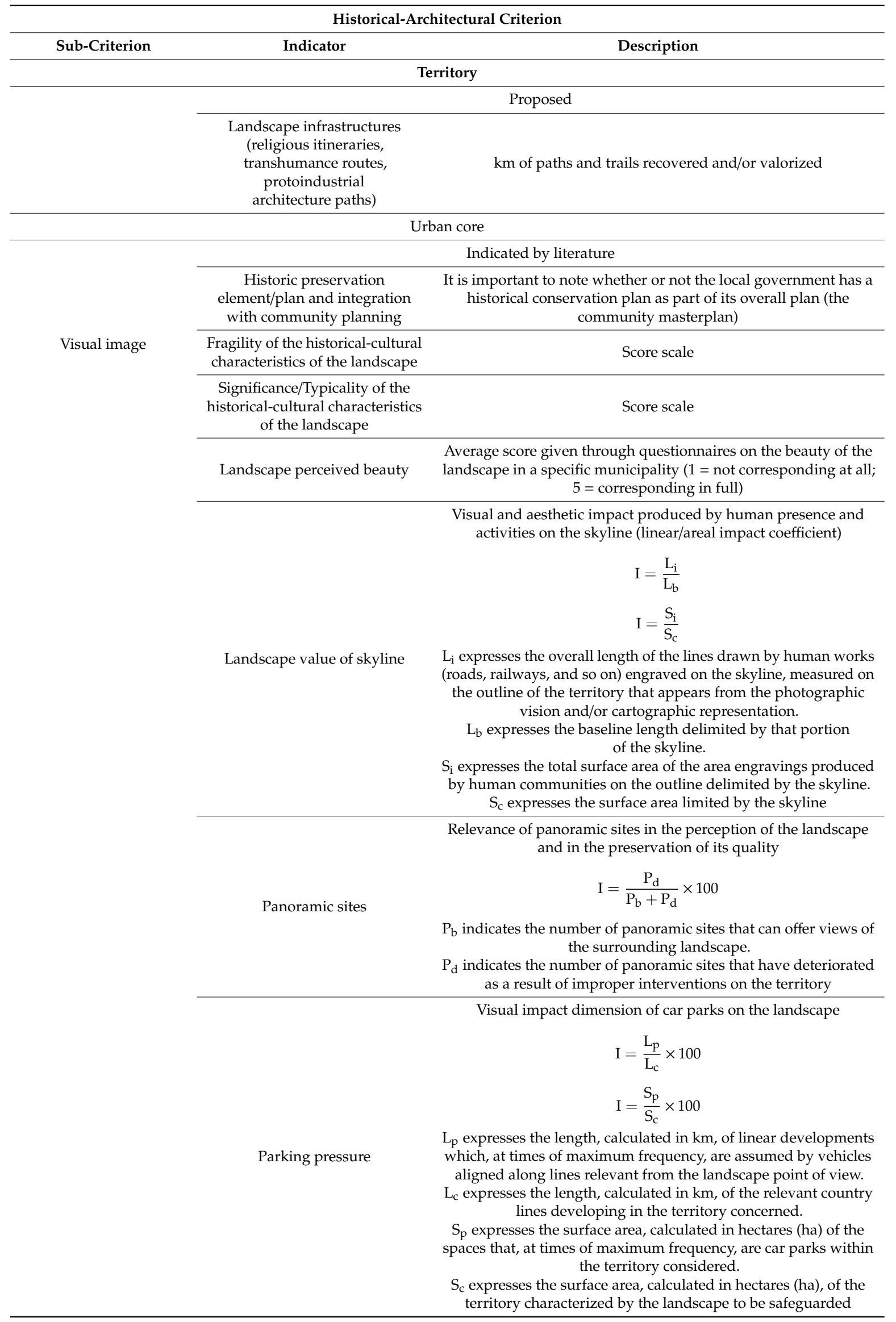


Table 8. Cont

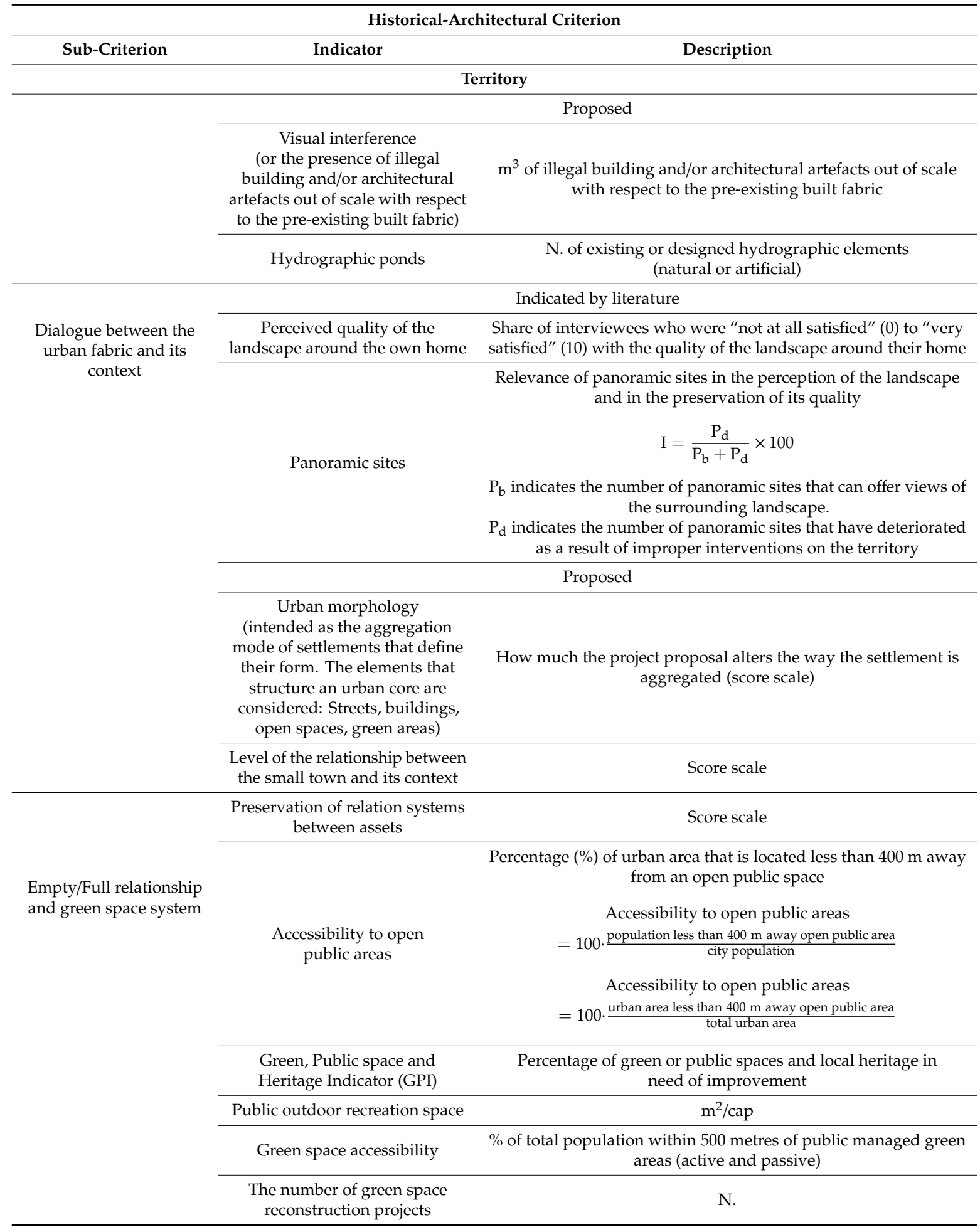


Table 8. Cont.

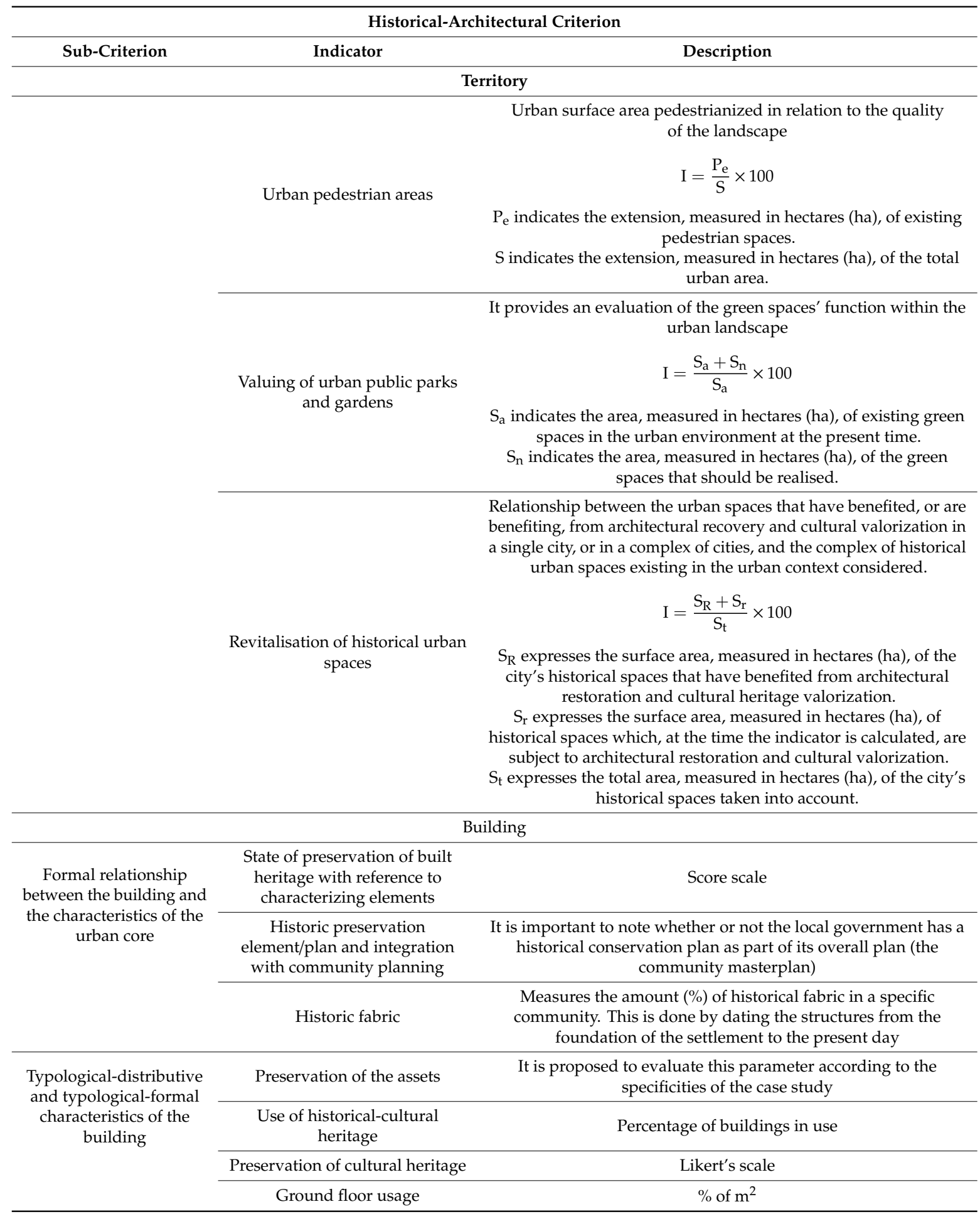

\section{Results and Discussion}

The research proposes novel datasets of criteria, sub-criteria, and corresponding indicators specifically defined for the multi-criteria evaluation of projects aimed at the recovery and valorization of small municipalities.

Based on the sustainable development principles, the four criteria are recognised: Social, economic, environmental, and historical-architectural. 
This is followed by the characterization of the sub-criteria, in light of extensive analysis conducted on the recurrent characteristics of the small town type, i.e., its 'invariants'.

Therefore, each sub-criterion is associated with several evaluation indicators, some taken from the articulated sector literature (see Table 3), others proposed. From a corpus of 470 indicators, they are then selected. This is done according to the methodological principles: Focus, relevance, accessibility, clarity, cost, frequency. Thus, it is possible to collect: 24 indicators for the social sub-criteria; 42 for the economic sub-criteria; 34 for the environmental ones; and 38 for the historical-architectural ones.

Tables 5-8 detail the study results, which are proposed as a methodological aid and a new operational tool for the effective selection of intervention initiatives in favour of small towns.

It becomes clear how important the work can be, since for the first time it indicates the complex components and parameters to be considered in the implementation of a multi-criteria models.

An hierchical model structured on the basis of the proposed criteria, sub-criteria, and indicators can be an important decision support system if local administrations intend to evaluate one or more valorization actions to be carried out or implemented. In fact, by comparing two or more project alternatives through the criteria and sub-criteria identified, it is possible to intervene concretely to propose improvements from a social, economic, environmental, or historical-architectural point of view. An AHP tool, thanks to the indicators that quantify the sub-criteria, is suitable to assess design weaknesses in order to strengthen them through strategic guidelines. The extensive dataset provided allows the designer/administrator to choose among multiple evaluation indicators, those most relevant to the specific case and whose necessary data can be more easily available.

Compared to the 17 Sustainable Development Goals (SDGs), the collapsed indicators have a specific and new focus on issues related to the social, economic, environmental, and historical-architectural aspects of small towns only. This means concentrating on the topics that affect these places in order to give a concrete and operational response to their valorization. In fact, enhancing these places means taking a first step towards the sustainable development of the territories. Moreover, starting from the problems of the individual small realities is the fundamental step to solve wider matters, such as those addressed by SDGs worldwide.

\section{Conclusions}

Valorizing the small towns is essential for the sustainable development of countries. There are several advantages: Greater healthiness of the air, possibility to reduce urban decongestion, opportunity to patch up the city-countryside relationship, redefinition of social and identity values, recovery of the built heritage, and reinstatement of local productive activities.

However, in the face of these multiple opportunities, the actions to be taken are complex. In fact, the widespread distance from big cities, the lack of adequate infrastructure, the insufficient basic services determine the absence of concrete job and housing possibilities, encouraging the population and especially the youngest to prefer the metropolitan life. Moreover, the multiple factors that characterize small towns are often different and conflicting, generating a frequent inability of local authorities to meet the site's needs. In this regard, the projects aimed only at the recovery of architectural artefacts are unsuitable to heal the numerous 'lacerations' of small realities: Interventions 'dropped from above', not consistent with the real necessities of the inhabitants and the territory, should be avoided.

Therefore, reasoned and organic actions are required, able to capture both social (local traditions, genius loci, schools, health facilities, markets, etc.), economic (productive activities, roads, parking, etc.), and environmental (flora and fauna, water, soil, air, etc.) aspects as well as the historical-architectural components of the village (visual-infrastructural-landscape relationship between the small town and the immediate context, formal relationship between building and urban core, etc.). It is imperative to extend the field of action, looking to the soul of places, respecting the traces that history has given to the present. 
In light of the above, the novelty of the research immediately emerges. The proposed datasets, in fact, allow the effective use of analysis tools able to support public administrations in the selection of valid strategies for the recovery and valorization of small municipalities.

Research perspectives concern the characterization of a hierarchical model of multi-criteria analysis, which can certainly be based on the criteria-subcriteria-indicators structure outlined in this work.

Author Contributions: Conceptualization, A.N. and P.F.; Data curation, A.N. and E.D.; Formal analysis, A.N., P.F. and E.D.; Investigation, A.N., P.F. and E.D.; Methodology, A.N., P.F. and E.D.; Project administration, A.N. and P.F.; Resources, E.D.; Software A.N., P.F. and E.D.; Supervision, A.N. and P.F.; Validation, A.N., P.F. and E.D.; Visualization, A.N., P.F. and E.D.; Writing—original draft, A.N. and E.D.; Writing—review \& editing, A.N., P.F. and E.D. All authors have read and agreed to the published version of the manuscript.

Funding: This research received no external funding.

Conflicts of Interest: The authors declare no conflict of interest.

\section{References}

1. Sau, A. La Rivitalizzazione Dei Borghi e Dei Centri Storici Minori Come Strumento per il Rilancio Delle Aree Interne. Federalismi.it. Rivista di Diritto Pubblico Italiano, Comparator, Europeo, n. 3, 31.01.2018. Available online: www.federalismi.it (accessed on 1 March 2020).

2. Paolella, A. Il Riuso Dei Borghi Abbandonati. Esperienze Di Comunità, 1st ed.; Pellegrini Editore: Cosenza, Italy, 2019.

3. Berizzi, C.; Rocchelli, L. Borghi Rinati. Paesaggi Abbandonati e Interventi di Rigenerazione, 1st ed.; Il Poligrafo: Padua, Italy, 2019.

4. Figueira, J.; Greco, S.; Ehrgott, M. Multiple Criteria Decision Analysis: State of the Art Surveys, 2nd ed.; Springer: New York, NY, USA, 2016.

5. Ribera, F.; Nesticò, A.; Cucco, P.; Maselli, G. A multicriteria approach to identify the Highest and Best Use for historical buildings. J. Cult. Herit. 2020, 41, 166-177. [CrossRef]

6. Ishizaka, A.; Nemery, P. Multi-Criteria Decision Analysis: Methods and Software, 1st ed.; John Wiley \& Sons: Chichester, UK, 2013.

7. Roy, B. Méthodologie Multicritére d'Aide à la Décision, 1st ed.; Economica: Paris, France, 1985.

8. Guitoni, A.; Martel, J.M. Tentative guidelines to help choosing an appropriate MCDA method. Eur. J. Oper. Res. 1998, 109, 501-521. [CrossRef]

9. Vincke, P. L'aide Multicritère à la Décision, 1st ed.; Université de Bruxelles: Bruxelles, Belgium, 1989.

10. Colson, G.; De Bruyn, C. Models and Methods in Multiple Criteria Decision Making, 1st ed.; Pergamon Press: Oxford, UK, 1989; Volume 23.

11. Fishburn, P.C. A survey of multiattribute/multicriterion evaluation theories. In Multiple Criteria Problem Solving, 1st ed.; Zionts, S., Ed.; Springer: Heidelberg, Germany, 1978; pp. 181-224.

12. Roy, B.; Bouyssou, D. Aide Multicritère à la Décision: Methodes et Cas, 1st ed.; Economica: Paris, France, 1993.

13. Keeney, R.L.; Raiffa, H. Decisions with Multiple Objectives: Preferences and Value Trade-Offs, 1st ed.; Cambridge University Press: Cambridge, UK, 1993.

14. De Montis, A. Analisi Multicriteri e Valutazione per la Pianificazione Territoriale, 1st ed.; CUEC Editrice: Cagliari, Italy, 2001.

15. Nesticò, A.; Somma, P. Comparative Analysis of Multi-Criteria Methods for the Enhancement of Historical Buildings. Sustainability 2019, 11, 4526. [CrossRef]

16. Mardani, A.; Jusoh, A.; Nor, K.; Khalifah, Z.; Zakwan, N.; Valipour, A. Multiple criteria decision-making techniques and their applications-A review of the literature from 2000 to 2014. Econ. Res. Ekonomska Istraživanja 2015, 28, 516-571. [CrossRef]

17. Di Gioia, V. Criteri di definizione dei centri storici. Civ. Delle Macch. 1975, 1-2, 25.

18. Coletta, T. I Centri Storici Minori Abbandonati della Campania. Conservazione, Recupero e Valorizzazione, 1st ed.; Edizioni Scientifiche Italiane: Naples, Italy, 2010.

19. Di Stefano, R. Il Recupero Dei Valori. Centri Storici e Monumenti. Limiti Della Conservazione e del Restauro, 1st ed.; Edizioni Scientifiche Italiane: Naples, Italy, 1979. 
20. Rocchi, G. Istituzioni di Restauro Dei Beni Architettonici e Ambientali, 1st ed.; Hoepli Editore: Milan, Italy, 1985.

21. Aa, V.V. Storia Dell'arte Italiana. Inchieste Su Centri Minori, 1st ed.; Giulio Einaudi Editore: Turin, Italy, 1980; Volume 1.

22. Tosco, C. Il Paesaggio Come Storia, 1st ed.; Il Mulino: Bologna, Italy, 2007.

23. Nesticò, A.; D’Andria, E.; Fiore, P. Centri Minori E Strategie Di Valorizzazione. In I Centri Minori ... Da Problema a Risorsa. Strategie Sostenibili per la Valorizzazione del Patrimonio Edilizio, Paesaggistico e Culturale Nelle Aree Interne, 1st ed.; Fiore, P., D’Andria, E., Eds.; FrancoAngeli: Milan, Italy, 2019; pp. 1397-1404.

24. Morris, M. Paure e Speranze Sul Futuro Dell'arte. Le Prospettive Dell'architettura Nella Civiltà, 1st ed.; Nuova Editrice Berti: Parma, Italy, 2012.

25. Carver, N.F. Borghi Collinari Italiani, 1st ed.; CLEAN Edizioni: Naples, Italy, 2017.

26. Nesticò, A.; He, S.; De Mare, G.; Benintendi, R.; Maselli, G. The ALARP Principle in the Cost-Benefit Analysis for the Acceptability of Investment Risk. Sustainability 2018, 10, 4668. [CrossRef]

27. Nesticò, A.; Guarini, M.R.; Morano, P.; Sica, F. An Economic Analysis Algorithm for Urban Forestry Projects. Sustainability 2019, 11, 314. [CrossRef]

28. Saaty, T.L. The Analytic Hierarchy Process; McGraw Hill: New York, NY, USA, 1980.

29. Saaty, T.L. Decision Making for Leaders: The Analytic Hierarchy Process for Decisions in a Complex World; RWS Publications: Pittsburgh, PA, USA, 1990.

30. Fusco Girard, L.; Nijkamp, P. Le Valutazioni per lo Sviluppo Sostenibile della Città e del Territorio, 3rd ed.; FrancoAngeli: Milan, Italy, 2000.

31. Neely, A.; Adams, C.; Kennerley, M. The Performance Prism; Financial Times/Prentice Hall: Upper Saddle River, NJ, USA, 2002.

32. Nesticò, A.; Maselli, G. Sustainability indicators for the economic evaluation of tourism investments on islands. J. Clean. Prod. 2020, 248, 119217. [CrossRef]

33. Mega, V.; Pedersen, J. Urban Sustainability Indicators, 1st ed.; Office for Official Publications of the European Communities: Luxembourg, 1998.

34. Mameli, F.; Marletto, G. A selection of indicators for monitoring sustainable urban mobility policies. In Trasporti, Ambiente e Territorio. La Ricerca di Un Nuovo Equlibrio, 1st ed.; Marletto, G., Musso, E., Eds.; FrancoAngeli: Milan, Italy, 2010; pp. 167-174.

35. Vallega, A. Indicatori per il Paesaggio, 1st ed.; FrancoAngeli: Milan, Italy, 2009.

36. Minx, J.; Creutzig, F.; Ziegler, T.; Owen, A. Developing a Pragmatic Approach to Assess Urban Metabolism in Europe. A report to the European Environment Agency, 1st ed.; Technische Universität Berlin and Stockholm Environment Institute, Climatecon: Berlin, Germany, 2011.

37. European Commission. Science for Environment Policy. In In-Depth Report: Indicators for Sustainable Cities; EEA Urban Metabolism Framework; Directorate-General Environment: Brussels, Belgium, 2018; p. 13.

38. United Nations Economic Commission for Europe. Transport for Sustainable Development in the ECE Region, 1st ed.; UNECE Transport Division: Geneva, Switzerland, 2011.

39. Volpiano, M. Indicators for the Assessment of Historic Landscape Features. In Landscape Indicators, 1st ed.; Cassatella, C., Peano, A., Eds.; Springer: Heidelberg, Germany, 2011; pp. 77-104.

40. Directorate-General for Agriculture and Rural Development. Rural Development in the European Union Statistical and Economic Information Report 2013, 1st ed.; European Union: Brussels, Belgium, 2013.

41. European Spatial Planning Observation Network (ESPON). Key Indicators for Territorial Cohesion and Spatial Planning, Part A, Executive Summary, 1st ed.; European Union: Brussels, Belgium, 2013.

42. Phillips, R.G.; Stein, J.M. An Indicator Framework for Linking Historic Preservation and Community Economic Development. Soc. Indic. Res. 2013, 113, 1-15. [CrossRef]

43. Valtenbergs, V.; González, A.; Piziks, R. Selecting Indicators for Sustainable Development of Small Towns: The Case of Valmiera Municipality. Procedia Comput. Sci. Spec. IssueIcte Reg. Dev. 2013, 26, 21-32.

44. European Environment Agency (EEA). Core Set of Indicators (CSI). In Digest of EEA Indicators 2014, 1st ed.; Aa, V.V., Ed.; European Environment Agency: Luxembourg, 2014; pp. 28-31.

45. UN-Habitat. Measurement of City Prosperity. Methodology and Metadata, 1st ed.; UN-Habitat: Nairobi, Kenya, 2016.

46. Bosch, P.; Jongeneel, S.; Rovers, V.; Neumann, H.-M.; Airaksinen, M.; Huovila, A. CITYkeys LIst of City Indicators, 1st ed.; CITYkeys: Brussels, Belgium, 2017. 
47. Troisi, R.; Alfano, G. Towns as Safety Organizational Fields: An Institutional Framework in Times of Emergency. Sustainability 2019, 11, 7025. [CrossRef]

48. Nesticò, A. L'Analisi Economica del Rischio di Progetto. Criteri e Tecniche. LaborEst 2019, 18, 41-48. [CrossRef]

(c)

(C) 2020 by the authors. Licensee MDPI, Basel, Switzerland. This article is an open access article distributed under the terms and conditions of the Creative Commons Attribution (CC BY) license (http://creativecommons.org/licenses/by/4.0/). 